\title{
On the taxonomic identity of the representatives of the brachyuran genus Pilumnus Leach, 1816 (Decapoda: Brachyura: Pilumnidae) occurring along the Russian coasts of the Black Sea
}

\section{О таксономической принадлезкности крабов рода Pilumnus Leach, 1816 (Decapoda: Brachyura: Pilumnidae), обитающих вдоль российского побережкья Черного моря}

\author{
Ivan N. Marin \\ Иван Н. Марин
}

\begin{abstract}
A.N. Severtzov Institute of Ecology and Evolution of RAS, Leninsky prosp., 33, Moscow 119071, Russia. E-mails: coralliodecapoda@mail.ru, vanomarin@yahoo.com

Институт проблем экологии и эволюции им. А.Н. Северцова РАН, Ленинский просп., 33, Москва, 119071 Россия.

Biological Department, Altai State University, Prospect Lenina, 61, Barnaul, 656049 Russia.

Биологический факультет, Алтайский Государственный Университет, пр-т Ленина, 61, Барнаул, 656049 Россия.
\end{abstract}

KEY WORDS: Crustacea, Decapoda, Pilumnidae, Pilumnus aestuarii, identity, species, Black Sea, Russian Federation.

КЛЮЧЕВЫЕ СЛОВА: Crustacea, Decapoda, Pilumnidae, Pilumnus aestuarii, определение, вид, Черное море, Российская Федерация.

ABSTRACT. Morphological and DNA-marker (COI mtDNA) analyses allowed to identify the representatives of the brachyuran genus Pilumnus Leach, 1816 (Decapoda: Pilumnidae) occurring along the Russian Federation coastline of the Black Sea as Pilumnus aestuarii Nardo, 1869. Earlier taxonomic identifications (e.g. Pilumnus hirtellus (Linnaeus, 1761)) and suggested scientific names for specimens from the Black Sea should be probably considered as misidentifications or junior synonyms of $P$. aestuarii.

How to cite this article: Marin I.N. 2018. On the taxonomic identity of the representatives of the brachyuran genus Pilumnus Leach, 1816 (Decapoda: Brachyura: Pilumnidae) occurring along the Russian coasts of the Black Sea // Arthropoda Selecta. Vol.27. No.2. P.111-120. doi: 10.15298/arthsel. 27.2.02

РЕЗЮМЕ. При помощи морфологического анализа и изучения генетических маркеров (ген субъединицы I митохондриальной цитохромоксидазы мтДНК) крабы рода Pilumnus Leach, 1816 (Decapoda: Pilumnidae), встречающиеся вдоль российского побережья Черного моря, идентифицированы как $P i$ lumnus aestuarii Nardo, 1869. Предыдущие определения данного вида (например, как Pilumnus hirtellus (Linnaeus, 1761)) и предлагаемые научные названия для экземпляров из Черного моря, вероятно, должны рассматриваться как ошибочные определения или младшие синонимы $P$. aestuarii.

\section{Introduction}

Investigations and inventory of decapod fauna (Crustacea: Decapoda) in the Azov - Black Sea basin have been carried out since the XVIII century and presently consists of 28 marine species with valid names, including a significant fraction of alien species such as widely distributed Rhithropanopeus harrisii (Gould, 1841) and Callinectes sapidus Rathbun, 1896 [Anosov, Ignatyev, 2016; Anosov et al., 2012, 2014]. However, there are still new records of decapod crustaceans and their associated fauna published from the region [e.g. Ashelby et al., 2013; Marin, 2013; Gavrilova, Dovgal, 2016; Revkov, 2016; Marin, Sokolova, 2014; Marin, Turbanov, 2016; Marin, 2017; Shalovenkov, 2017; Guchmanidze et al., 2017; Marin, in press] whereas some cases of the local extinction of particular species have been also reported [Anosov, Timofeev, 2016]. At the same time, the current decapod species list form the Black Sea include the number of species identified by the analogy with the species from European seas in early years of faunistic research. Since that time their taxonomic status has not been clarified using the modern taxonomic methods, for example, molecular-genetic analysis. Among such species there is a widespread representative of the brachyuran genus Pilumnus Leach, 1816 (Decapoda: Pilumnidae) occurring along the Russian coasts of the Black Sea, which morphological variability even allowed the description of several Black sea subspecies (see Czerniavsky, 1884; Spiridonov, 


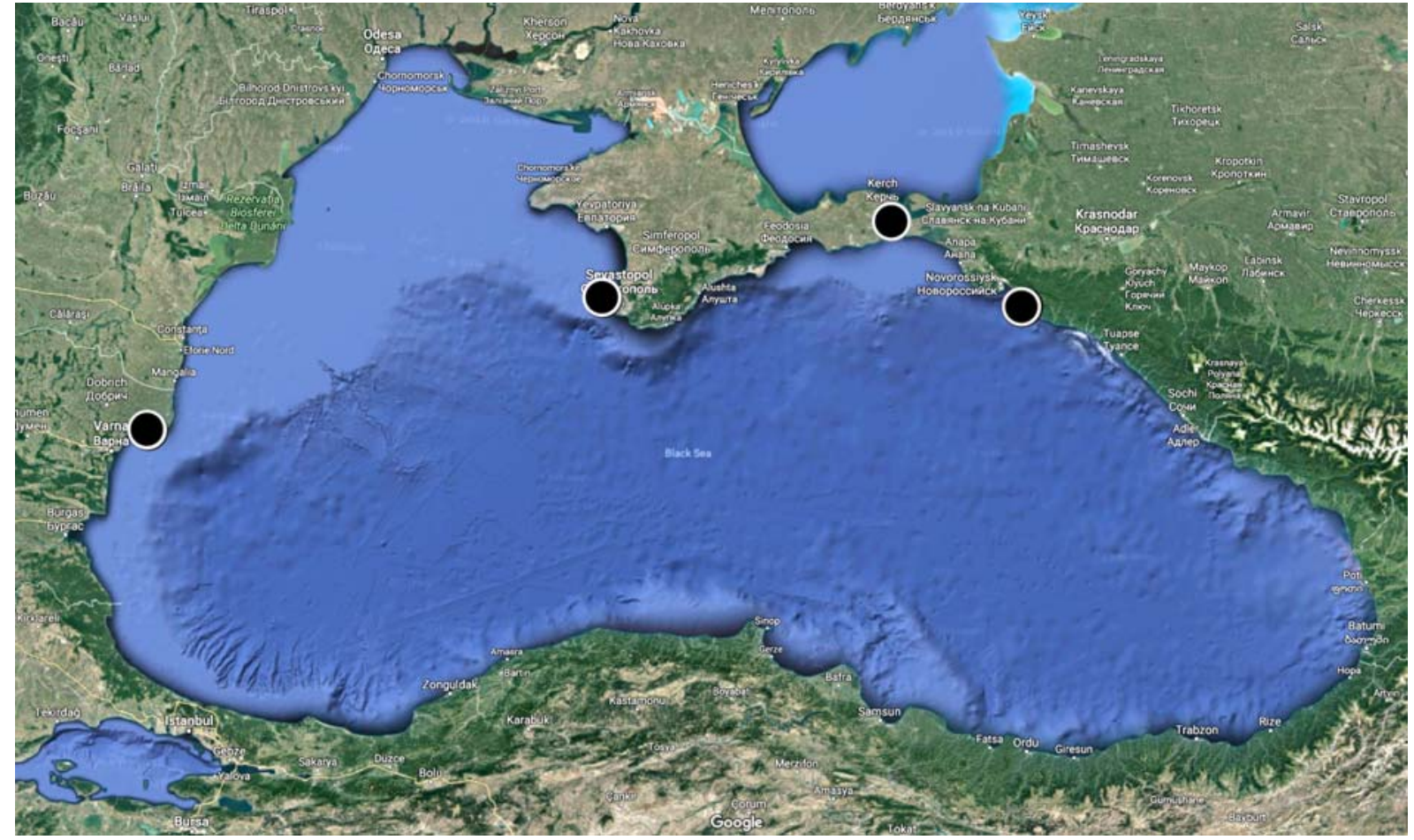

Fig. 1. Map of localities along the coasts of the Black Sea where the representatives of the crab genus Pilumnus was sampled. The material from Bulgaria (Kavarna) is taken from GenBank (NCBI - HG328358.1) (see in the text).

Рис. 1. Карта сбора материала вдоль побережья Черного моря, где были собраны представители рода Pilumnиs. Материал из Болгарии (Каварна) взят из GenBank (NCBI - HG328358.1) (см. текст).

Petryashov, 2011) not recognized later [e.g. Bãcescu, 1967; Kobjakova, Dolgopolskaya, 1968; Makarov, 2004; Ng et al., 2008].

During the study of decapod biodiversity along the Russian coast of the Black Sea as a part of a project of inventory of Russian decapod fauna, numerous representatives of the genus Pilumnus were collected. A comparison of collected crabs with the ñomparison of collected crabs to recognizable characters in the original descriptions of Pilumnus hirtellus (Linnaeus, 1761) and Pilumnus aestuarii Nardo, 1869, including presented figures (see Fig. 2a) as well as DNA analysis based on the genetic barcode of COI (nucleotide sequence of the cytochrome c oxidase subunit I gene) mtDNA revealed that previous identification of the species as " $P$. hirtellus" is incorrect: the Black Sea specimens belong to brackish-water $P$. aestuarii distributed both in the Mediterranean and Black Sea (according to Türkay et al. [1987]; Schubart [2014]). Several authors support the presence of the specific Mediterranean-Black Sea group or clade within the European Pilumnus probably belonging to $P$. aestuarii (after Schubart [2014]) on the basis of morphology and molecular genetic data [Bãcescu, 1967; Zariquiey Alvarez, 1968; Kobjakova, Dolgopolskaya, 1969; Türkay et al., 1987; Müller, Schubart, 2007; Ng et al., 2008; Oliveira-Biener et al., 2010; Schubart et al., 2012; Schubart, 2014]. The present communication aims to demonstrate that the Pilumnus specimens from the Rus- sian coasts of the Black Sea clearly belong to this welldefined clade referred as to Pilumnus aestuarii.

\section{Material and Methods}

Fieldwork and sampling were carried out along the Russian coasts of the Black Sea: the Kazachiya Bay

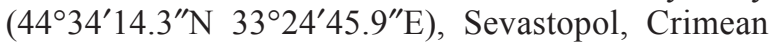
Peninsula (August-October 2015), the Taman Bay $\left(45^{\circ} 14^{\prime} 52.9^{\prime \prime} \mathrm{N} 36^{\circ} 51^{\prime} 16.0^{\prime \prime} \mathrm{E}\right)$, Taman, Krasnodar region (July 204, August 2015) and the Blue Bay (443”30.1"N 3757'05.1"E), Gelendzhik, Krasnodar region (September 2009) (Fig. 1). The material was collected by snorkeling from the depth of 2-10 m. Coloration and morphology of alive specimens were photographed using Canon Power Shot G16. All specimens were preserved in $90 \%$ ethanol for further DNA analysis. Carapace width (cw., $\mathrm{mm}$ ), the maximal length between lateral margins of carapace, is used as a standard measurement. Species names and modern taxonomic position are given according to $\mathrm{Ng}$ et al. (2008), the international species database WoRMS (World Register of Marine Species) and Marine Species Identification Portal. Only primary species synonyms are given. The examined material is deposited in the collection of Zoological Museum of Moscow State University, Moscow (ZMMU) and personal author collection (LEMMI) deposited in A.N. Severtzov Institute of Ecol- 
ogy and Evolution of Russian Academy of Sciences, Moscow, Russia.

DNA analysis of collected specimens and comparison with sequences of European Pilumnus species presented in GenBank (NCBI) database (see Schubart [2014]) is used for exact species identification (see Appendix 1). For this aim, a fragment of the gene marker of mtDNA coding for cytochrome c oxidase subunit I gene (COI mtDNA) was amplified, sequencing and compared. Total genomic DNA was extracted from abdominal and pereiopod muscle tissue using the innuPREP DNA Micro Kit (AnalitikJena, Germany) following the manufacturer's protocol. The mitochondrial marker COI was amplified with the help of PCR Core (Isogene Lab., Moscow) using the universal primers LCO1490 (5'-ggtcaacaaatcataaagatattgg-3') and HC02198 (5'-taaacttcagggtgaccaaaaaatca-3') [Folmer et al. 1994]. PCR was performed on amplificator, Tercik DNA Technology under the following conditions: initial denaturation at $96^{\circ} \mathrm{C}$ for $1.5 \mathrm{~min}$ followed by 42 cycles of $95^{\circ} \mathrm{C}$ for $2 \mathrm{~min}, 55^{\circ} \mathrm{C}$ for 35 seconds, and $72^{\circ} \mathrm{C}$ for $1.5 \mathrm{~min}$, annealing at $59^{\circ} \mathrm{C}$ for 45 seconds, followed by chain extension at $72^{\circ} \mathrm{C}$ for $7 \mathrm{~min}$. The volume of $20 \mathrm{uL}$ of reaction mixture contained $5 \mathrm{uL}$ of total DNA, $10 \mathrm{uL}$ of PCR diluent and $2.5 \mathrm{uL}$ of each primer. The amplification products were separated by using gel electrophoresis on a $2 \%$ agarose gel in 1xTBE, and then stained and visualized with $0.003 \%$ EtBr using imaging $U V$ software. The resulting PCR products were sequenced in both forward and reverse direction by "EuroGen" (Moscow, Russia). Sequences were examined in BioEdit v. 5.0.9. The resulting 658 base pair (bp) COI mtDNA sequences were registered in GenBank (NCBI). The aligned COI mtDNA dataset was analyzed for divergence using the Kimura-2-parameter (K2P) distance model with MEGA 7.0. The received nucleotide alignments of COI mtDNA gene were used to construct the phylogenetic trees using MaximumLikelihood (ML) algorithm in MEGA 7.0.

The study of population structure of the species was accomplished by sampling all crabs in two different biotopes where crabs were previously observed to be markedly different in size (see Fig. 3j): (1) eutrophic communities of the Taman Bay and (2) fairly organically poor rocky boulders of the Kazachiya Bay. The bottom communities of the Taman Bay form a complex ecosystem with a large number of biotopes, a high diversity of benthic organisms and complex multi-component communities. One of the most important factors of the high diversity and eutrophication of the Bay is the presence of extensive nearby areas occupied by macrophytes (sea grasses and algae) that create favorable conditions for the development of multi-level communities, including both periphyton and bottom zoobenthos as well as a variety of bottom sediments including all types of bottom substratum: sand, clayey silt, silt, clayey-sandy mud with high detritus content, shell rock, marl, pebbles, rocks and rocks. Accordingly, the bottoms sites in this area are represented by various biotopes with psammophilic and pelophilic communities with domination of sponges, polychaetes Nephtys cirrus, mollusks Mytilus galloprovincialis, Cerastoderma glaucum and Hydrobia, areas with hard clay outlet with predominance of burrowing bivalves Barnea candida and others [Golovkina, Nabozhenko, 2012; Biryukova et al., 2016; Spiridonov et al., 2016; Zalota et al., 2017]. In contrast, bottom communities of the outer part of the Kazachiya Bay, where crabs where collected, are represented mainly by rocky boulders or artificial hard substrates, overgrowing with various macrophytes, clusters of mussels, other fouling organisms and underlying sandy bottom at a depth of more than $10-15 \mathrm{~m}$. The bay is characterized by the presence of a large number of shelters for macrofauna and zoobenthos, and a low level of sedimentation in its outer part and significantly washed into tidal cycles and during strong storms, so there is not much accumulation of organic matter and eutrophication as in the Taman Bay [e.g. Evstigneeva et al., 2015].

\section{Results}

Family Pilumnidae Samouelle, 1819

Genus Pilumnus Leach, 1816

Pilumnus aestuarii Nardo, 1869

Fig. 2.

Pilumnus aestuarii Nardo, 1869: 297, Tab. XII-6 [type locality — lagoon of Venice, Italy]

Pilumnus aestuarii. — Zariquiey Alvarez, 1968: 393; Türkay et al., 1987: 98, Figs. 6a, b.

MATERIAL EXAMINED. North Atlantic Ocean, Black Sea, Russian Federation: 2 males (LEMMI) - Krasnodar region, Ge-

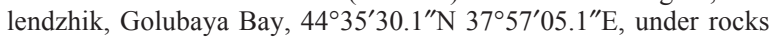
and boulders, depth 2 m, coll. I. Marin, S. Anosov, 10 Sept. 2009; 18 ovigerous females; 25 males (LEMMI) - Crimean Peninsula,

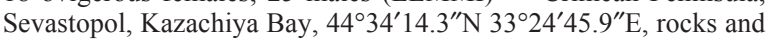
clusters of Mytilus cf. galloprovincialis, depth $2 \mathrm{~m}$, coll. I. Marin, I. Turbanov, G. Turbanov, 6-8 Aug. 2015; 10 females and 10 males (LEMMI) - Krasnodar region, Taman, Taman Bay, $45^{\circ} 14^{\prime}$ $52.9^{\prime \prime} \mathrm{N} 36^{\circ} 51^{\prime} 16.0^{\prime \prime} \mathrm{E}$, under rocks and boulders, depth $2 \mathrm{~m}$, coll. I. Marin, S. Sinelnikov, August 2015.

EXTENDED DIAGNOSIS. Carapace quadrilateral, glabrous, covered with sparse thick, brush-like plumose setae (Fig. $2 a-e$ ); regions indistinct, frontal margin divided with deep medial groove into two prominent lobes, frontal and supraorbital margins with a marked rim (Fig. 2f); anterolateral margin of carapace with five sharp, forward pointing teeth, with the posterior teeth being larger (Fig. 2f); orbital margins dorsally denticulated; sternal surfaces smooth. Chelipeds unequal, with smooth and glabrous segments; carpus unarmed; propodus (palm) smooth and glabrous, without distinct teeth; surface of fingers glabrous and smooth, cutting margins armed with large blunt rounded teeth, the proximal teeth being larger, especially on large cheliped. Ambulatory legs long, densely covered with stiff plumose setae in small specimens (Fig. 3d) and less pubescent in large specimens (Fig. $2 b-e$ ) merus unarmed, without spines or granules (Fig. $2 b-e$ ). Abdomen consists of five articulating segments, distal 

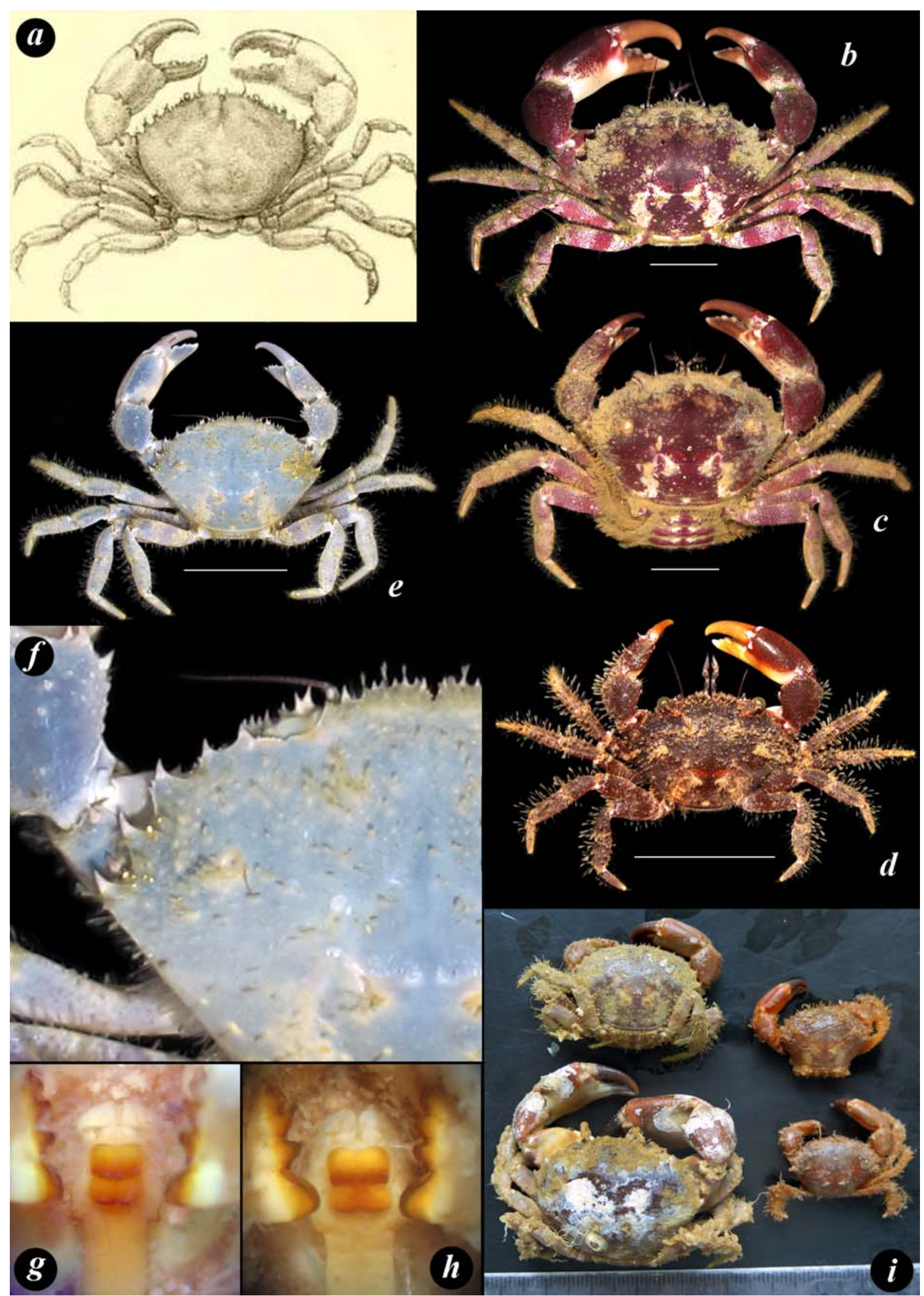
segment triangular, with rounded distal margin, slightly shorter than penultimate segment. Gastric urocardiac ossicle with blunt cubic dorso-median tooth possessing rounded corners, mesocardiac ossicles wellmarked (Fig. $2 g, h$ ). Gonopod I sinous, tip distinctly bent downwards, subterminal portion with numerous long thin simple setae; gonopod II short, with terminal flagellum.

TAXONOMIC REMARKS. The original description of $P$. aestuarii presented by Nardo [1869] described a large male specimen possessing cw. about 36 mm (18 lines) (Fig. 2a) similar to the largest male specimen collected during our study in the Taman Bay of the Black Sea (see Fig. $2 j$ ). According to the original description, $P$. aestuarii can be morphologically separated from $P$. hirtellus by glabrous carapace and chelae with only sparse plumose setae similar to large specimens from the Taman Bay (see Fig. 2b,c,e). However, smaller specimens from the Kazachiya Bay possess the carapace more densely covered with numerous plumose setae (Fig. 2d,f) that could be considered as a character varying with size. The lack of spinulation on the palm of the larger chela of $P$. aestuarii mentioned by Zariquiey Alvarez [1968] as the distinctive feature can be also considered as a reliable character for the separation from specimens of $P$. hirtellus from the East Atlantic and North Sea that possess distinct granulation on proximal part of propodus (palm) of both small and large chelae [e.g. Adema, 1991: fig. 72]. Schubart [2014] also suggested using urocardiac and mesocardiac gastric ossicle for the species identification; and the ossicles in examined specimens from the Black Sea (Fig. $2 h, i$ ) are similar to the ones characteristic for $P$. aestuarii showed by Schubart [2014: Fig. 3A, B]. An additional morphological feature mentioned by Zariquiey Alvarez [1968], namely slenderness of the pereiopods of $P$. hirtellus in comparison to $P$. aestuarii (P3 merus length/width ratio in $P$. aestuarii vs. $P$. hirtellus is 3.56:2.31 while P5 merus length/width ratio in $P$. aestuarii vs. $P$. hirtellus is $3.56: 1.65$ ), was not evaluated as no available similar sized specimens of $P$. hirtellus were examined during the study.

COLORATION. Crabs collected in Russian waters of the Black Sea have deeply red or reddish-brown carapaces and appendages; chelipeds and walking legs are reddish-brown in general color with yellowish distal segments; finger tips of chelipeds brown or yellow in young specimens (see Fig. $2 b-d$ ). An atypical blue colored male specimen (Fig. $2 e, f$ ) was collected during the study in the Taman Bay. The coloration of $P$. aestuarii from Black Sea is generally similar to Atlantic P. hirtellus [i.e., Ingle, 1997].
HABITAT AND ECOLOGY. Subtidal species, ecologically similar to Mediterranean-Aegean congeners, living among algae, piles of mollusk shell, especially mussel Mytilus spp., rocks and boulders from the intertidal zone to the depth of $30 \mathrm{~m}$.

SIZE AND POPULATION STRUCTURE. The largest collected male (Taman Bay) possess cw. $35 \mathrm{~mm}$ and female (Taman Bay) - cw. $28 \mathrm{~mm}$. The largest collected male from the Kazachiya Bay have cw. 22 $\mathrm{mm}$ while female - cw. $20 \mathrm{~mm}$; specimens from the Golubaya Bay (Gelendzhik) are mostly similar in size to the Kazachiya Bay. The structure of crab populations from the Taman and Kazachiay Bays is also different (Fig. 4): population in the Kazachiya Bay is abundant and represented by numerous specimens living under rocks and boulders differing in size from smaller juveniles $(10 \mathrm{~mm})$ to adult specimens $(20+$ $\mathrm{mm})$, which, however, are much smaller than specimens collected in the Taman Bay (see Fig. 2i). At the same time, crabs are rarer and population is represented by large (extremely large for Pilumnus spp. which usually reach to 20-25 mm size (after Zariquiey Alvarez [1968]; Türkay et al. [1987]; Adema [1991]; Mavidis et al. [2009]; pers. observ.) adult specimens exclusively, while no juveniles were found during our intensive studies in the Taman Bay (Fig. 4). The difference in the composition of populations can be explained by the number of available food objects on soft bottoms (Taman Bay) and hard biotopes (rocky boulders in the Kazachiya and Golubaya Bays), the present of more shelters for the survival of juveniles and young individuals on rocky substrates and migration of large crabs to food-rich habitats.

DISTRIBUTION. The species is recorded from Crimean Peninsula to Caucasian coastline along Russian coasts of the Black Sea. Widely distributed, probably mainly in brackish waters, in the Mediterranean and Aegean seas from the Bosphorus Strait to the coasts of Morocco [Oliveira-Biener et al., 2010; Schubart et al., 2012; Schubart, 2014].

PHYLOGENETIC ANALYSIS. Results of phylogenetic reconstruction based on COI mtDNA gene using Maximum-Likelihood algorithm (Fig. 3) support a separate position and close relation of the studied $P i$ lumnus specimens from the Russian coasts of the Black Sea to Mediterranean - Black Sea clade of $P$. aestuarii (after Schubart [2014]). This clade is clearly separated from Eastern Atlantic P. hirtellus as well as Mediterranean $P$. spinifer and $P$. villosissimus.

Fig. 2. Pilumnus aestuarii Nardo, 1869: $a$ - from Nardo, 1869, $b, c, e, f, h$ - Taman Bay, $d$ - Golubaya Bay (Gelendzhik), $g$ Kazachiya Bay: $a, b, d, e$ - male, general dorsal view; $c$ - female, general dorsal view; $g, h$ - urocardiac region of the gastric ossicles, males; $i$ - largest collected specimens from the Taman Bay (left row) and the Kazachiya Bay (right row), female (above) and male (below).

Рис. 2. Pilumnus aestuarii Nardo, 1869: $a$ - из Nardo, 1869, b, $c, e, f, h-$ экземпляры из Таманского залива, $d-$ экземпляры из Голубой залив (Геленджик), $g$ - экземпляры из Казачьей бухты: $a, b, d, e-$ самец, общий вид сверху; $c$ - самка, общий вид сверху; $g, h$ - карапакс, вид сверху, самцы; $g, h$ - центральная область желудочной мельницы, самцы; $i$ - наиболее крупные собранные экземпляры крабов из Таманского залива (левый ряд) и Казачьей бухты (правый ряд), самки (сверху) и самцы (снизу). 


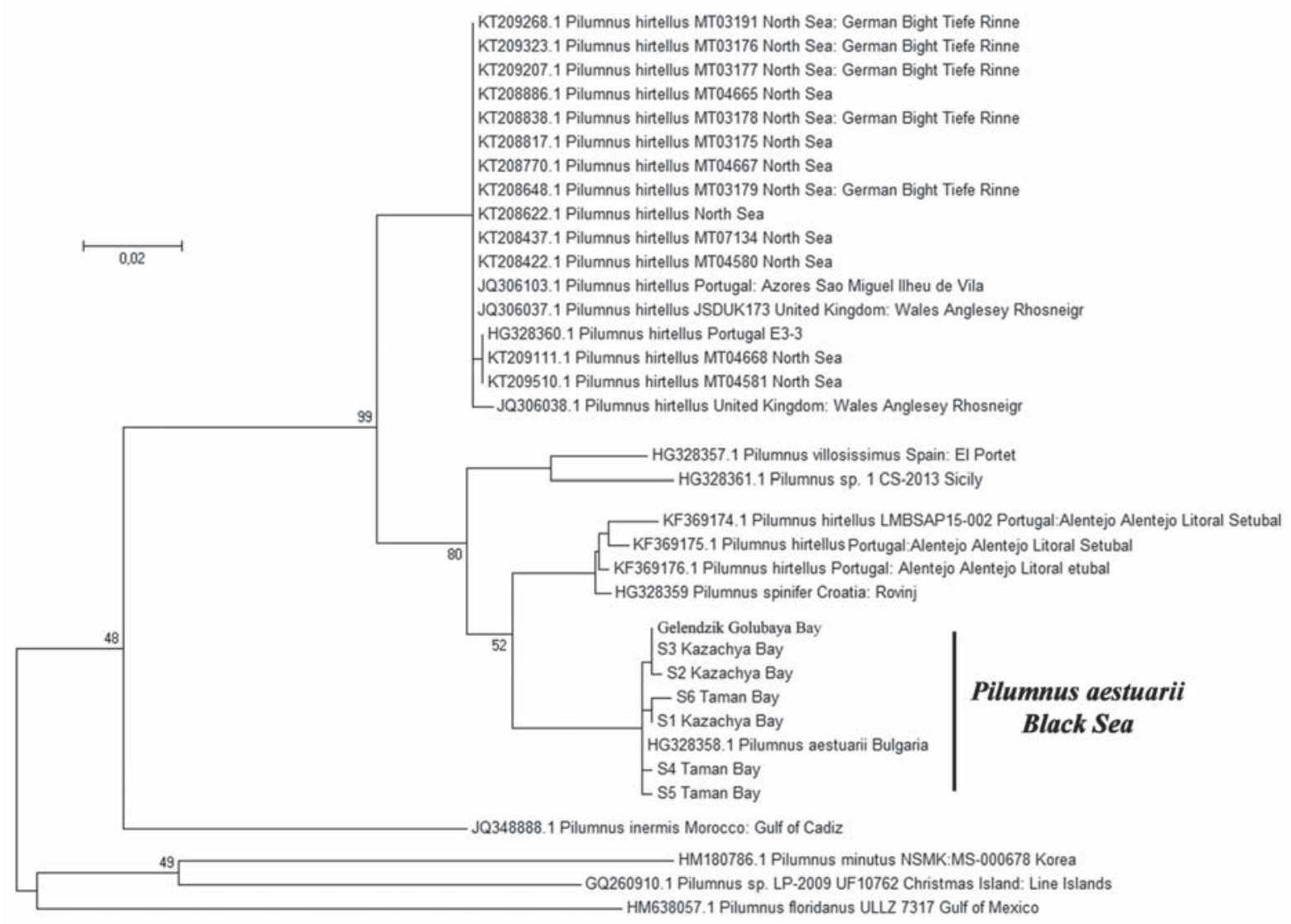

Fig. 3. Maximum-Likelihood phylogenetic reconstruction based on COI mtDNA gene marker of studied Pilumnus samples from the Black Sea and available sequences from GenBank (NCBI).

Рис. 3. Филогенетическая реконструкция на основе алгоритма максимального правдоподобия маркера маркеров COI мтДНК изученных образцов Pilumnus из Черного моря и доступных последовательностей из GenBank (NCBI).

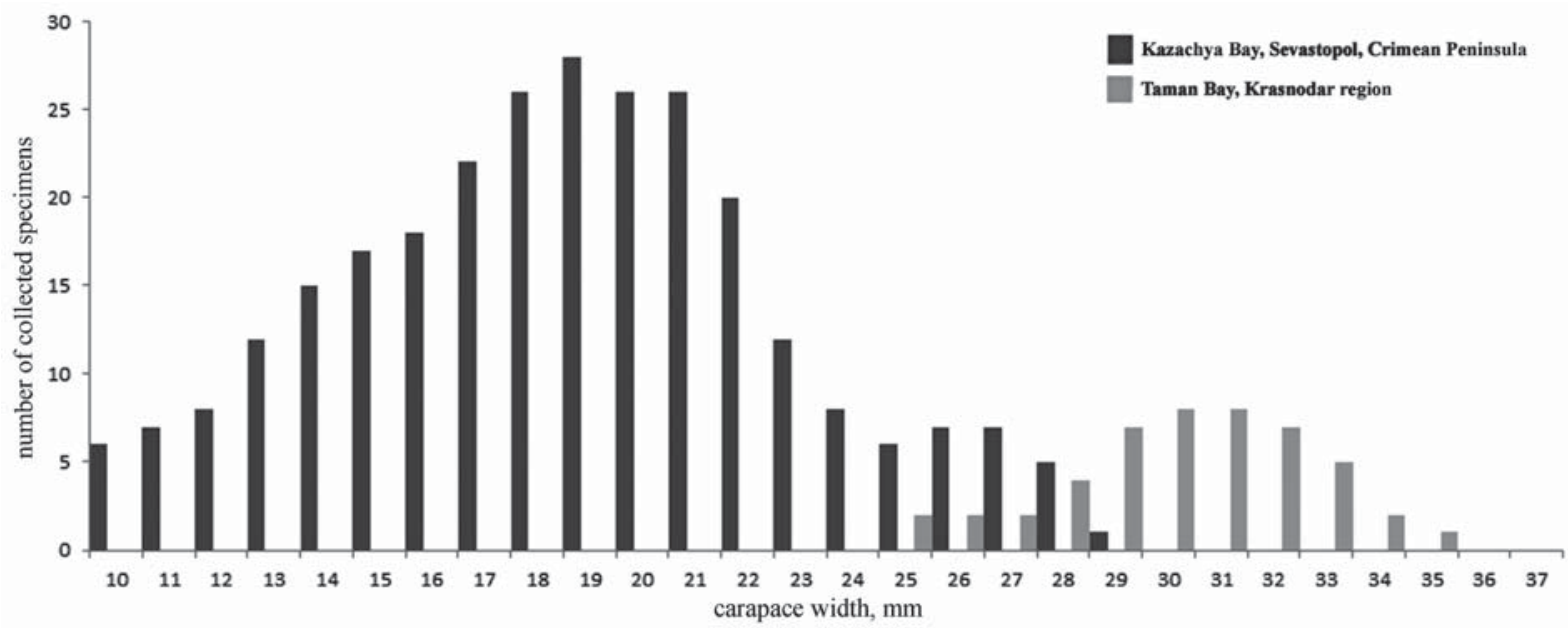

Fig. 4. Size structure of Pilumnus aestuarii Nardo, 1869 from the Kazachiya (6-8 Aug. 2015) and Taman bays (August 2015). Рис. 4. Размерный состав Pilumnus aestuarii Nardo, 1869 из Казачьей бухты (6-8 августа 2015 г.) и Таманского залива (август 2015 г.) 


\section{Discussion}

Pilumnus aestuarii is considered by many authors as a junior synonym of $P$. hirtellus in view of very similar external morphology [e.g. Mavidis et al., 2009]. At the same time, molecular-genetic data (see OliveiraBiener et al. [2010]; Schubart [2014]) shows the presence of a separate Mediterranean - Black Sea clade within the European Pilumnus, not conforming to Eastern Atlantic $P$. hirtellus, and the Mediterranean species $P$. spinifer or $P$. villosissimus. This clade can be identified as $P$. aestuarii (see Schubart [2014]). All crabs of the genus Pilumnus collected during this study along the Russian coasts of the Black Sea refer exclusively to this clade (see Fig. 2). The obtained COI sequences most closely match to the sequence HG328358.1 deposited in GenBank (NCBI). The sequence HG328358.1 is characteristic for the haplogroup referring to $P$. aestuarii [Schubart, 2014] (Fig. 3) and, most interesting, it belongs to the specimen collected from the Black Sea (Bulgaria, Kavarna) (see Fig. 1). Moreover, Pilumnus aestuarii was described from the shallow and brackish (salinity about 20\%o) and highly eutrophic lagoon of Venice (Nardo, 1869) of the Adriatic Sea, which is similar to the Taman Bay of the Black Sea by the environmental conditions and the biota characteristic to for transitional waters [Spiridonov et al., 2016]. In the Adriatic and the Mediterranean Seas such lagoons characterized by lower salinity and higher eutrophication represent separate biotopes clearly different from fully saline tidally washed biotopes of the Eastern Atlantic and the NorthSea where true $P$. hirtellus occurs [Zariquiey Alvarez, 1968; Türkay et al., 1987; Müller, Schubart, 2007; Mavidis et al., 2009; Oliveira-Biener et al., 2010; Schubart et al., 2012; Schubart, 2014]. Generally, marine biotopes similar to natural habitats of $P$. hirtellus is harder to find in the Black Sea than brackish biotopes characteristic for brackish-water $P$. aestuarii, considering the overall low salinity (18-20\%o) in the Black Sea. Apparently, a tolerance to low salinity allowed this brackish-water species to penetrate the Black Sea, while the remaining Mediterranean species of the genus Pilumnus have never been found in the Black Sea Basin. In this regard, we can also assume that eutrophic soft bottom communities of the Taman Bay, where crabs reach larger sizes, are probably more suitable for this species than highly washed rocky biotopes characteristic for the Caucasian Coast (Gelendzhik) and coasts of Crimean Peninsula (Kazachiya Bay). However, this issue requires a more detailed ecological analysis.

\section{ACKNOWLEDGEMENTS}

Author is very grateful to Sergey Yu. Sinelnikov and Ilya S. Turbanov (I.D. Papanin Institute for Biology of Inland Waters of RAS, Borok, Russia) for the help in field sampling and DNA extraction.

\section{References}

Adema J.P.H.M. 1991. De krabben van Nederland en Belgie (Crustacea, Decapoda, Brachyura) [The crabs of the Netherlands and Belgium (Crustacea, Decapoda, Brachyura)] // Nationaal Natuurhistorisch Museum: Leiden, The Netherlands. 244 pp.

Anosov S.E., Ignatyev S.M. 2016. [History of the study of Pontian decapods] // Morskoi Biologicheskiy Zhurnal [Marine Biological Journal]. Vol.1. No.1. P.93-101 [in Russian].

Anosov S.E., Spiridonov V.A., Marin I.N. 2012. A revised checklist of the Black Sea Decapoda // Abstracts of contributions presented at the TCSSM 2012 and the 10-th CCDM, 3-7 June 2012, Athens, Greece. P.124.

Anosov S.E., Timofeev V.A. 2016. Vanishing of isolated population of thick clawed crayfish Astacus pachypus (Crustacea: Decapoda: Astacidae) in Sevastopol Bay (Crimean Peninsula, Black Sea) // Arthropoda Selecta. Vol.25. No.1. P.63-66.

Anosov S.E., Marin I.N., Petryashov V.V., Sokolov V.I., Spiridonov V.A. 2014. An attempt of the first complete contemporary inventory of decapod (Crustacea: Decapoda) species richness in the seas of the Russian Federation // Abstracts of Contributions of $8^{\text {th }}$ International Crustacean Congress (ICC8). Frankfurt on Main. August, 18-23, 2014. P.11.

Ashelby C.W., De Grave S., Johnson M.L. 2013. The global invader Palaemon macrodactylus (Decapoda, Palaemonidae): an interrogation of records and a synthesis of data // Crustaceana. Vol.86. No.5. P.594-624. http://dx.doi.org/10.1163/156. 85403-0000320.

Bãcescu M. 1967. Decapoda // Fauna Republicii Socialiste Romania. Crustacea. Bucuresti. Vol.4. No.9. P.1-351.

Biryukova S.V., Syomin V.L., Gromov V.V. 2016. [State of the Taman Bay bottom communities after the construction of the Tuzla dam in the Kerch strait] // Nauka Yuga Rossii (Vestnik Yuznogo Nauchnogo Centra) [Science in the South of Russia]. Vol.12. No.2. P.53-67 [in Russian].

Czerniavsky V.I. 1884. Crustacea Decapoda pontica. Khar'kov: V Universitetskoi tipografii. 268 p. [in Latin and Russian].

Evstigneeva I.K., Grintsov V.A., Lisitskaja E.V., Makarov M.V., Tankovskaya I.N. 2015. [Biodiversity of macrophytes communities Kasachia Bay] // Bulleten' Moskovskogo Obshestva Ispytateley Prirody, Otdeleni Biologii [Bulletin MOIP]. Vol.120. No.6. P.51-64 [in Russian].

Folmer O., Black M., Hoeh W., Lutz R., Vrijenhoek R. 1994. DNA primers for amplification of mitochondrial cytochrome c oxidase subunit I from diverse metazoan invertebrates // Molecular Marine Biology \& Biotechnology. Vol.3. P.294-299

Gavrilova N.A., Dovgal I.V. 2016. Tintinnid ciliates (Spirotrichea, Choreotrichia, Tintinnida) of the Black Sea: recent invasions // Protistology. Vol.10. No.3. P.91-96.

Golovkina E.M., Nabozhenko M.V. 2012. [Contemporary condition of benthic communities of Kerch strait (the Russian sector) and gulfs of Taman Peninsula] // Nauka Yuga Rossii (Vestnik Yuznogo Nauchnogo Centra) [Science in the South of Russia]. Vol.8. No.2. P.53-61 [in Russian].

Guchmanidze A., Statkevich S.V., Boltachev A.R. 2017. The first record of prawn Penaeus semisulcatus De Haan, 1844 (Decapoda, Penaeidae) near the coast of Georgia // Russian Journal of Biological Invasions. Vol.8. No.1. P.14-17 [in Russian].

Ingle R. 1997. Crayfishes, Lobsters and Crabs of Europe. An Illustrated Guide to Common and Traded Species. New York: Chapman and Hall. 281 pp.

Kobjakova Z.I., Dolgopolskaya M.A. 1969. [Otryad desiatinogie - Decapoda] // Mordukhai-Boltovskoy F.D. (ed.) Opredelitel fauny Chernogo i Azovskogo morey. Tom 2. Svobodnozhivuschie bespozvonochnye. Rakoobraznye. Order Decapoda. [Field guide for the Black and Azov Seas. Vol.2. Free-living invertebrates. Crustaceans.] Kiev: Naukova Dumka. P.207-306 [in Russian].

Makarov Y.N. 2004. [Desyatinogie rakoobraznye - Decapoda] // Fauna Ukrainy [Fauna of Ukraine]. Vol.26. No.1-2. 427 pp. [in Russian]. 
Marin I.N. 2013. Atlas of Decapod Crustaceans of Russia. Moscow: KMK Scientific Press. 145 pp.

Marin I. 2017. Troglocaris (Xiphocaridinella) kumistavi sp. nov., a new species of stygobiotic atyid shrimp (Crustacea: Decapoda: Atyidae) from Kumistavi Cave, Imereti, Western Georgia, Caucasus // Zootaxa. Vol.4311. No.4. P.576-588.

Marin I. (in press). Cryptic diversity of stygobiotic shrimp genus Xiphocaridinella Sadowsky, 1930 (Crustacea: Decapoda: Atyidae): the first case of species co-occurrence in the same cave system in the Western Caucasus // Zootaxa.

Marin I. (in press). Xiphocaridinella shurubumi sp. nov. (Crustacea: Decapoda: Atyidae) — a new stygobiotic atyid shrimp species from Shurubumu and Mukhuri Caves, Chkhorotsku, Western Georgia, Caucasus // Zoologicheskii Zhurnal.

Marin I., Sokolova A. 2014. Redescription of the stygobiotic shrimp Troglocaris (Xiphocaridinella) jusbaschjani Birštein, 1948 (Decapoda: Caridea: Atyidae) from Agura River, Sochi, Russia, with remarks on other representatives of the genus from Caucasus // Zootaxa. Vol.3754. No.3. P.277-298.

Marin I.N., Turbanov I.S. 2016. The first record of the copepod genus Clausidium Kossmann, 1875 (Crustacea: Copepoda: Poecilostomatoida: Clausiididae) parasitic on burrowing callianassid shrimps from the Black Sea // Arthropoda Selecta. Vol.25. No.4. P.381-384.

Mavidis M., Kitsos M.-S., Türkay M., Koukouras A. 2009. The taxonomical status of the genus Pilumnus Leach, 1815 (Pilumnidae, Decapoda, Crustacea) in the Mediterranean Sea, focusing on three species in the Aegean Sea // Journal of Biological Resources. Vol.11. P.13-20.

Müller C.H.G., Schubart C.D. 2007. Insights into the Crustacea Decapoda of the Adriatic Sea. Observations from four sampling locations along the Croatian coast // Rostocker Meeresbiologische Beiträge. Vol.18. P.112-130.

Ng P.K.L., Guinot D., Davie P.J.F. 2008. Systema Brachyurorum: Part I. An annotated checklist of extant brachyuran crabs of the World // Raffles Bulletin of Zoology. Vol.17. P.1-286.

Nardo G.D. 1869 Annotazioni illustranti cinquantaquattro specie di crostacei podottalmi, endottalmi e succhiatori del Mare Adriatico, alcune delle quali nuove o mal conosciute, accompagnate da trentatre figure litografate, e precedute dalla storia della carcinologia Adriatica antica e recente // Memorie del Reale The Istituto Veneto di Scienze, Lettere ed Arti. Vol.14. P.217-343.

Oliveira-Biener U., Melzer R.R., Miller M.A. 2010. Pilumnus Leach (Decapoda: Pilumnidae Samouelle) from Mediterranean and adjacent Atlantic waters: a COI analysis // Invertebrate Systematics. Vol.24. P.182-193. https://doi.org/10.1071/IS09051 Revkov N.K. 2016. [Colonization features of the Black Sea basin by recent invader Anadara kagoshimensis (Bivalvia: Arcidae)] // Morskoi biologicheskii zhurnal [Marine biological journal]. Vol.2. P.3-17 [in Russian].

Schubart C.D., Guerao G., Abelló P. 2012. First record and evidence of an established population of the North American mud crab Dyspanopeus sayi (Brachyura: Heterotremata: Panopeidae) from the western Mediterranean // Scientia Marina. Vol.76. P.79-85.

Schubart C.D. 2014. Determination of evolutionary units in European representatives of the crab genus Pilumnus // Central European Journal of Biology. Vol.9. No.1. P.104-113. http:// dx.doi.org/10.2478/s11535-013-0242-5.

Shalovenkov N. 2017. Non-native zoobenthic species of the Crimean Black Sea Coast // Mediterranean Marine Science. Vol.18/2. P.260-270. http://dx.doi.org/10.12681/mms.1925.

Spiridonov V.A., Kolyuchkina G.A., Belyaev N.A., Basin A.B., Kozlovsky V.A. 2016. Contemporary condition of macrozoobenthos in ultrashallow zone of Taman Bay, Sea of Azov // Oceanology. Vol.56. P.248-258. https://doi.org/10.1134/ S0001437016020193

Spiridonov V.A., Petryashov V.V. 2011. Type specimens of the Crustacea Decapoda taxa described by Alexaner Brandt and Vladimir Czerniavsky from the Black Sea in the collection of the Zoological Institute of the Russian Academy of Science, St.Petersburg (with notes on type specimens of the decapod species described by Heinrich Rathke from Crimea) // Monografie del Museo Regionale di Scienze Naturali di Torino. Vol.40. P.259-293.

Türkay M. 2001. Decapoda // Costello M.J., Emblow C., White R. (eds.). European register of marine species: a check-list of the marine species in Europe and a bibliography of guides to their identification. Collection Patrimoines Naturelles. Vol.50. P.284-292.

Zalota A.K., Kolyuchkina G.A., Tiunov A.V., Birjukova S.V., Spiridonov V.A. 2017. The trophic position of an alien crab, Rhithropanopeus harrisii (Crustacea, Decapoda, Panopeidae), in the Taman Bay, Sea of Azov community // Oceanology. Vol.57. No.2. P.289-297. https://doi.org/10.1134/ S0001437017020217

Zariquiey Alvarez R. 1968. Crustaceos decapodos Ibéricos // Investigacion pesquera. Vol.32. P.1-510.

Responsible editor V.A. Spiridonov 
Appendix 1. List and nucleotide sequences of crab specimens used for molecular-genetic analysis.

Приложение 1. Список и нуклеотидные последовательности экземпляров крабов, использованных для молекулярно-генетического анализа.

\begin{tabular}{|c|c|}
\hline Locality & Nucleotide sequence (658 base pair) of COI mtDNA \\
\hline $\begin{array}{l}1 \text { male (LEMMI) - North Atlantic Ocean, } \\
\text { Black Sea, Russian Federation, Krasnodar } \\
\text { region, Gelendzhik, Golubaya Bay, } \\
44^{\circ} 35^{\prime} 30.1^{\prime \prime} \mathrm{N} 37^{\circ} 57^{\prime} 05.1^{\prime \prime} \mathrm{E} \text {, under rocks and } \\
\text { boulders, depth } 2 \mathrm{~m} \text {, coll. I. Marin, S. Anosov, } \\
10 \text { Sept. } 2009\end{array}$ & $\begin{array}{l}\text { \#S7_Golubaya_Bay (Gelendzik) } \\
\text { TAAATGTTGATAAAGCACCGGGTCACCCCCTCCGGCAGGGTCAAAGAAAGA } \\
\text { GGTATTTAAATTACGGTCTGTAAGAAGCATAGTAATAGCTCCTGCCAATACT } \\
\text { GGTAAAGATAAAAGAAGCAGAATTGCGGTAATAAATACAGCTCATACAAAA } \\
\text { AGCGGTATTTGATCTATTGATATACCAAAAGATCGCATGTTGATTACGGTAG } \\
\text { TCATAAAGTTAACTGCTCCTAAGATGGAAGAAACTCCTGCCAAATGAAGAG } \\
\text { AGAAGATTCCTATATCTACTGAGGCACCTGCATGAGCAATAGCTGCAGCCAA } \\
\text { AGGAGGGTAAACTGTTCAACCAGTACCCACTCCTCTTTCTACTATCCCTCTTA } \\
\text { TTAGAAGAAGAGTAAGAGAAGGAGGGAGTAATCAAAATCTTATATTATTTA } \\
\text { TACGAGGAAAAGCTATATCCGGAGCTCCTAATATTAGAGGAACTAGTCAGTT } \\
\text { CCCAAATCCTCCAATTATAATGGGTATCACTATAAAAAAAATTATAACAAAA } \\
\text { GCGTGGGCTGTAACTACAACATTGTAAATCTGATCATTACCAATTAATGTCC } \\
\text { CAGGTTGCCCTAATTCGGCTCGAATAATTAAACTTAATGAGGTTCCTACTATT } \\
\text { CCAGCTCAGCCTCCAAAGATGAAAT }\end{array}$ \\
\hline
\end{tabular}

2 males and 1 female (LEMMI) - North Atlantic Ocean, Black Sea, Russian Federation, Crimean Peninsula, Sevastopol, Kazachiya Bay, $44^{\circ} 34^{\prime} 14.3^{\prime \prime} \mathrm{N} 33^{\circ} 24^{\prime} 45.9^{\prime \prime} \mathrm{E}$, rocks and clusters of Mytilus cf. galloprovincialis, depth $2 \mathrm{~m}$, coll. I. Marin, I. Turbanov, G. Turbanov, 6-8 Aug. 2015

\section{\#S1 Kazachiya Bay}

TAĀATGTTGĀTAAAGCACCGGGTCACCCCCTCCGGCAGGGTCAAAGAAAGA GGTATTTAAATTACGGTCTGTAAGAAGCATAGTAATAGCTCCTGCCAATACT GGTAAAGATAAAAGAAGTAGAATTGCGGTAATAAATACAGCTCATACAAAA AGCGGTATTTGATCTATTGATATACCAAAAGATCGCATGTTGATTACGGTAG TCATAAAGTTAACTGCTCCTAAGATGGAAGAAACTCCTGCCAAATGAAGAG AGAAGATTCCTATATCTACTGAGGCACCTGCATGAGCAATGGCTGCAGCCAA AGGAGGGTAAACTGTTCAACCAGTACCCACTCCTCTTTCTACTATCCCTCTTA TTAGAAGAAGAGTAAGAGAAGGAGGGAGTAATCAAAATCTTATATTATTTA TACGAGGAAAAGCTATATCCGGAGCTCCTAATATTAGAGGAACTAGTCAGTT CCCAAATCCTCCAATTATAATGGGTATCACTATAAAAAAAATTATAACAAAA GCGTGGGCTGTAACTACAACATTGTAAATCTGATCATTACCAATTAATGTCC CAGGTTGCCCTAATTCGGCTCGAATAATTAAACTTAATGAGGTTCCTACTATT CCAGCTCAGCCTCCAAAGATGAAAT

\#S2_Kazachiya_Bay

TAAATGTTGĀTAAAGCACCGGGTCACCCCCTCCGGCAGGGTCAAAGAAAGA GGTATTTAAATTACGGTCTGTAAGAAGCATAGTAATAGCTCCTGCCAATACT GGTAAAGATAAAAGAAGCAGAATTGCGGTAATAAATACAGCTCATACAAAA AGCGGTATTTGATCTATTGATATACCAAAAGATCGCATGTTGATTACGGTAG TCATAAAGTTAACTGCTCCTAAGATGGAAGAAACTCCTGCCAAATGAAGAG AGAAGATTCCTATATCTACTGAGGCACCTGCATGAGCAATGGCTGCAGCCAA AGGAGGGTAAACTGTTCAACCAGTACCCACTCCTCTTTCTACTATCCCTCTTA TTAGAAGAAGAGTAAGAGAAGGAGGGAGTAATCAAAATCTTATATTATTTA TACGAGGAAAAGCTATATCCGGAGCTCCTAATATTAGAGGAACTAGTCAGTT CCCAAATCCTCCAATTATAATGGGTATCACTATAAAAAAAATTATAACAAAA GCGTGGGCTGTAACTACAACATTGTAAATCTGATCATTACCAATTAATGTCC CAGGTTGCCCTAATTCGGCTCGAATAATTAAACTTAATGAGGTTCCTACTATT CCAGCTCAGCCTCCAAAGATGAAAT

\#S3 Kazachiya Bay

TAĀATGTTGĀTAAAGCACCGGGTCACCCCCTCCGGCAGGGTCAAAGAAAGA GGTATTTAAATTACGGTCTGTAAGAAGCATAGTAATAGCTCCTGCCAATACT GGTAAAGATAAAAGAAGCAGAATTGCGGTAATAAATACAGCTCATACAAAA AGCGGTATTTGATCTATTGATATACCAAAAGATCGCATGTTGATTACGGTAG TCATAAAGTTAACTGCTCCTAAGATGGAAGAAACTCCTGCCAAATGAAGAG AGAAGATTCCTATATCTACTGAGGCACCTGCATGAGCAATAGCTGCAGCCAA AGGAGGGTAAACTGTTCAACCAGTACCCACTCCTCTTTCTACTATCCCTCTTA TTAGAAGAAGAGTAAGAGAAGGAGGGAGTAATCAAAATCTTATATTATTTA TACGAGGAAAAGCTATATCCGGAGCTCCTAATATTAGAGGAACTAGTCAGTT CCCAAATCCTCCAATTATAATGGGTATCACTATAAAAAAAATTATAACAAAA GCGTGGGCTGTAACTACAACATTGTAAATCTGATCATTACCAATTAATGTCC CAGGTTGCCCTAATTCGGCTCGAATAATTAAACTTAATGAGGTTCCTACTATT CCAGCTCAGCCTCCAAAGATGAAAT 


\section{Locality}

2 males and 1 female (LEMMI) - North Atlantic Ocean, Black Sea, Russian Federation, Krasnodar region, Taman, Taman Bay, $45^{\circ} 14^{\prime} 52.9^{\prime \prime} \mathrm{N} \quad 36^{\circ} 51^{\prime} 16.0^{\prime \prime} \mathrm{E}$, under rocks and boulders, depth $2 \mathrm{~m}$, coll. I. Marin, S. Sinelnikov, August 2015

\section{Nucleotide sequence (658 base pair) of COI mtDNA}

\#S4 Taman Bay

TAÄATGTTGATAAAGCACCGGGTCACCCCCTCCGGCAGGGTCAAAGAAAGA GGTATTTAAATTACGGTCTGTAAGAAGCATAGTAATAGCTCCTGCCAATACT GGTAAAGATAAAAGAAGTAGAATTGCGGTAATAAATACAGCTCATACAAAA AGCGGTATTTGATCTATTGATATACCAAAAGATCGCATGTTGATTACGGTAG TCATAAAGTTAACTGCTCCTAAGATGGAAGAAACTCCTGCCAAATGAAGAG AGAAGATTCCTATATCTACTGAGGCACCTGCATGAGCAATAGCTGCAGCCAA AGGAGGGTAAACTGTTCAACCAGTACCCACTCCTCTTTCTACTATCCCTCTTA TTAGAAGGAGAGTAAGAGAAGGAGGGAGTAATCAAAATCTTATATTATTTA TACGAGGAAAAGCTATATCCGGAGCTCCTAATATTAGAGGAACTAGTCAGTT CCCAAATCCTCCAATTATAATGGGTATCACTATAAAAAAAATTATAACAAAA GCGTGGGCTGTAACTACAACATTGTAAATCTGATCATTACCAATTAATGTCC CAGGTTGCCCTAATTCGGCTCGAATAATTAAACTTAATGAGGTTCCTACTATT CCAGCTCAACCTCCAAAGATGAAAT

\#S5_Taman_Bay

TAĀATGTTGATAAAGCACCGGGTCACCCCCTCCGGCAGGGTCAAAGAAAGA GGTATTTAAATTACGGTCTGTAAGAAGCATAGTAATAGCTCCTGCCAATACT GGTAAAGATAAAAGAAGTAGAATTGCGGTAATAAATACAGCTCATACAAAA AGCGGTATTTGATCTATTGATATACCAAAAGATCGCATGTTGATTACGGTAG TCATAAAGTTAACTGCTCCTAAGATGGAAGAAACTCCTGCCAAATGAAGAG AGAAGATTCCTATATCTACTGAGGCACCTGCATGAGCAATAGCCGCAGCCAA AGGAGGGTAAACTGTTCAACCAGTACCCACTCCTCTTTCTACTATCCCTCTTA TTAGAAGAAGAGTAAGAGAAGGAGGGAGTAATCAAAATCTTATATTATTTA TACGAGGAAAAGCTATATCCGGAGCTCCTAATATTAGAGGAACTAGTCAGTT CCCAAATCCTCCAATTATAATGGGTATCACTATAAAAAAAATTATAACAAAA GCGTGGGCTGTAACTACAACATTGTAAATCTGATCATTACCAATTAATGTCC CAGGTTGCCCTAATTCGGCTCGAATAATTAAACTTAATGAGGTTCCTACTATT CCAGCTCAACCTCCAAAGATGAAAT

\#S6 Taman_Bay

TAĀATGTTGATAAAGCACCGGGTCACCCCCTCCGGCAGGGTCAAAGAAAGA GGTATTTAAATTACGGTCTGTAAGAAGCATAGTAATAGCTCCTGCCAATACT GGTAAAGATAAAAGAAGTAAAATTGCGGTAATAAATACAGCTCATACAAAA AGCGGTATTTGATCTATTGATATACCAAAAGATCGCATGTTGATTACGGTAG TCATAAAGTTAACTGCTCCTAAGATGGAAGAAACTCCTGCCAAATGAAGAG AGAAGATTCCTATATCTACTGAGGCACCTGCATGAGCAATGGCTGCAGCCAA AGGAGGGTAAACTGTTCAACCAGTACCCACTCCTCTTTCTACTATCCCTCTTA TTAGAAGAAGAGTAAGAGAAGGAGGGAGTAATCAAAATCTTATATTATTTA TACGAGGAAAAGCTATATCCGGAGCTCCTAATATTAGAGGAACTAGTCAGTT CCCAAATCCTCCAATTATAATGGGTATCACTATAAAAAAAATTATAACAAAA GCGTGGGCTGTAACTACAACATTGTAAATTTGATCATTACCAATTAATGTCC CAGGTTGCCCTAATTCGGCTCGAATAATTAAACTTAATGAGGTTCCTACTATT CCAGCTCAACCTCCAAAGATGAAAT 